\title{
Spatio-temporal variation of planktonic decapods along the leeward coast of the Fernando de Noronha archipelago, Brazil
}

\author{
Claudeilton Severino de Santana ${ }^{1 *}$, Ralf Schwamborn ${ }^{1}$, Sigrid Neumann-Leitão ${ }^{1}$, Manuel de Jesus \\ Flores Montes ${ }^{1}$, Simone Maria de Albuquerque Lira ${ }^{l}$
}

\author{
${ }^{1}$ Universidade Federal de Pernambuco \\ (Av. Arquitetura, s/n - Cidade Universitária - Recife - PE - 50740-550 - Brazil) \\ *Corresponding author: claudeilton.ssantana@gmail.com
}

\section{Abstract}

Tropical island environments are considered hotspots due to their high diversity, endemism and ecological importance. However, reports that discuss the composition and ecology of planktonic decapods in these environments are still very few. In order to ascertain the composition, abundance and spatial-temporal distribution of planktonic decapods, zooplankton samples were taken by means of sub-surface hauls with a standard plankton net of $300 \mu \mathrm{m}$ mesh size. Sampling was carried out at five stations in the nearshore leeward area of the Fernando de Noronha archipelago, in July and December 2013 and June and November 2014. A total of 22 decapod taxa were recorded, among which the most abundant were Brachyura (zoeae), Clibanarius sp., Caridea and Callianassidae. Characteristic annual distribution and temporal tendencies were observed for the larvae of the hermit crab Clibanarius sp. and for the larvae of burrowing shrimps (Callianassidae). Some taxa showed differences between sampling stations. In general, higher abundances were observed in the southern (downstream) stations of the island (Baía dos Golfinhos and Cacimba do Padre), and lower abundances in the northernmost (upstream) station (Porto de Santo Antônio), indicating the existence of larval retention in the nearshore coastal zone of this oceanic island ecosystem.

Descriptors: Tropical oceanic islands, Zooplankton, Decapod larvae, Horizontal distribution, Microscale variation.

\section{RESUMO}

Ambientes insulares tropicais são considerados verdadeiros hostspots devido a sua alta diversidade, endemismo e importância ecológica. Contudo, ainda são poucos os trabalhos que abordam a composição e ecologia de decápodes planctônicos nesses ambientes. Para determinar a composição, abundância e distribuição espaço-temporal dos decápodes planctônicos, as amostras de zooplâncton foram coletadas por meio de arrastos subsuperficiais em rede cônico-cilíndrica com $300 \mu \mathrm{m}$ de abertura de malha. A amostragem foi realizada em cinco estações na área costeira a sotavento do Arquipélago de Fernando de Noronha, em julho e dezembro de 2013 e junho e novembro de 2014 . Foram registrados 22 táxons de Decapoda, dos quais Brachyura (zoea); Clibanarius sp.; Caridea e Callianassidae foram os grupos mais abundantes. Foram observadas tendências de distribuição anual e temporal para as larvas de Clibanarius sp. e Callianassidae, respectivamente. Alguns táxons apresentaram diferenças entres as estações de amostragem. De forma geral, as maiores densidades larvais foram observadas nas estações ao sul da ilha (Baía dos Golfinhos e Cacimba do Padre) em relação aos menores valores registrados para a estação mais ao norte (Porto de Santo Antônio), indicando a existência de uma possível retenção larval à jusante, na zona costeira interna desse ecossistema insular oceânico.

Descritores: Ilhas oceânicas tropicais, Zooplâncton, Larvas de Decapoda, Distribuição horizontal, Variação em microescala. 


\section{INTRODUCTION}

Decapod crustaceans are usually known, as adults, for their economic importance (De Grave et al., 2009). However, many of these organisms present a planktonic larval phase, with specific adaptive mechanisms that permit this way of life (Williamson, 1969; Anger, 2001). During their larval stage marine decapods are dispersed by the displacement of water masses (Scheltema, 1988; Strathmann et al., 2002; Koettker and Freire, 2006). The distribution of these organisms is largely influenced by environmental factors such as currents, temperature, salinity, nutrients, light, food availability and duration of the larval cycle. These factors can influence composition, abundance and diversity of planktonic decapods (Anger, 2001; Strathmann et al., 2002; Gibson, 2003; Landeira et al., 2010). Studies on the larval ecology of Decapoda are essential to the understanding of the marine ecosystems in which they are inserted (Schwamborn et al., 1999; Anger, 2001; Brandão et al., 2012, 2013). Even so, little effort has been made to assess the distribution and composition of decapod larvae in oceanic island environments in Brazil (Koettker et al., 2010; Brandão et al., 2012, 2013; Marafon-Almeida et al., 2016), specifically for the Fernando de Noronha archipelago (Lira et al., 2014, 2017, 2018).

Insular environments in the Tropical Atlantic Ocean are considered true oases in the middle of an oligotrophic blue desert (Boltovskoy, 1981). The phenomenon that enriches the waters around such islands is known as "Island mass effect" (Doty and Oguri, 1956). This effect increases considerably the planktonic biomass in these environments (Doty and Oguri, 1956; Gove et al., 2016). Additional factors are current, eddies and winds, which may lead to retention, depending on their interaction with the local geological features (Brandão et al., 2012, 2013; Landeira et al., 2013). Previous studies have observed that in more sheltered (leeward) locations of oceanic islands there was a higher abundance of planktonic organisms than at more external (windward) sites of the islands (e.g. Le Borgne et al., 1985; Hernández-León, 1991). However, there is no information available on the microscale distribution and potential retention patterns of planktonic decapods on the leeward side of tropical oceanic islands. Detailed small-scale studies of zooplankton in the leeward regions of oceanic islands are of paramount importance for the detailed description of the distribution of planktonic decapods on different time scales (e.g. inter-annual and seasonal).
This study aims to assess the distribution of planktonic decapods in the nearshore leeward region of the Fernando de Noronha archipelago over a period of two years. We tested the hypothesis that planktonic decapods display spatial (as between stations) and temporal (as between seasons and years) differences in abundance. Specifically, this study seeks to ascertain the possible existence of a larval abundance gradient between the stations in the northernmost (upstream) and southern (downstream) zones in the nearshore leeward area of the Fernando de Noronha archipelago, that may be related to possible retention phenomena.

\section{MATERIAL AND METHODS}

\section{STUDY AREA}

This study was conducted in the leeward coastal region of the Fernando de Noronha archipelago (FN), (0351'S, $32^{\circ} 25^{\prime} \mathrm{W}$ ) (Figure 1), a small archipelago of volcanic origin located in the Tropical Atlantic Ocean. This archipelago is inserted in a specific marine protected area and in a National Marine Park. FN is a summit that rises 4,200 m above the ocean bed as one of a chain of seamounts (De Almeida, 1955; Weaver, 1990). The currents that influence the archipelago belong to the Southern Equatorial Current (SEC) system, which travels East-West, approximately parallel to the equator (Stramma, 1991; Silveira et al., 2000).

During the study season, temperature and salinity presented minimum values of $26.53^{\circ} \mathrm{C}$ (dry season of 2014) and 35.7 (rainy season 2013) and maximum values of $29.23^{\circ} \mathrm{C}$ (rainy season of 2014) and 36.3 (dry season of both years), respectively. The nutrient level was considered normal for the oligotrophic regions of the Tropical Atlantic Ocean, with inter-annual seasonal variation (2014 with higher nutrient concentrations), though with low levels of ammonia. A sudden increase of nutrients was recorded during the rainy seasons of the two years (see Assunção et al., 2016).

\section{SAMPLING STRATEGY}

Four oceanographic expeditions were carried out on the Fernando de Noronha archipelago (FN) during the rainy (July 2013 and June 2014) and the dry season (December 2013 and November 2014) along the leeward coast. The samples were collected in a small boat at five stations: Porto de Santo Antônio (PSA), Praia do Cachorro (PC), Praia da Conceição (CON), located in the 


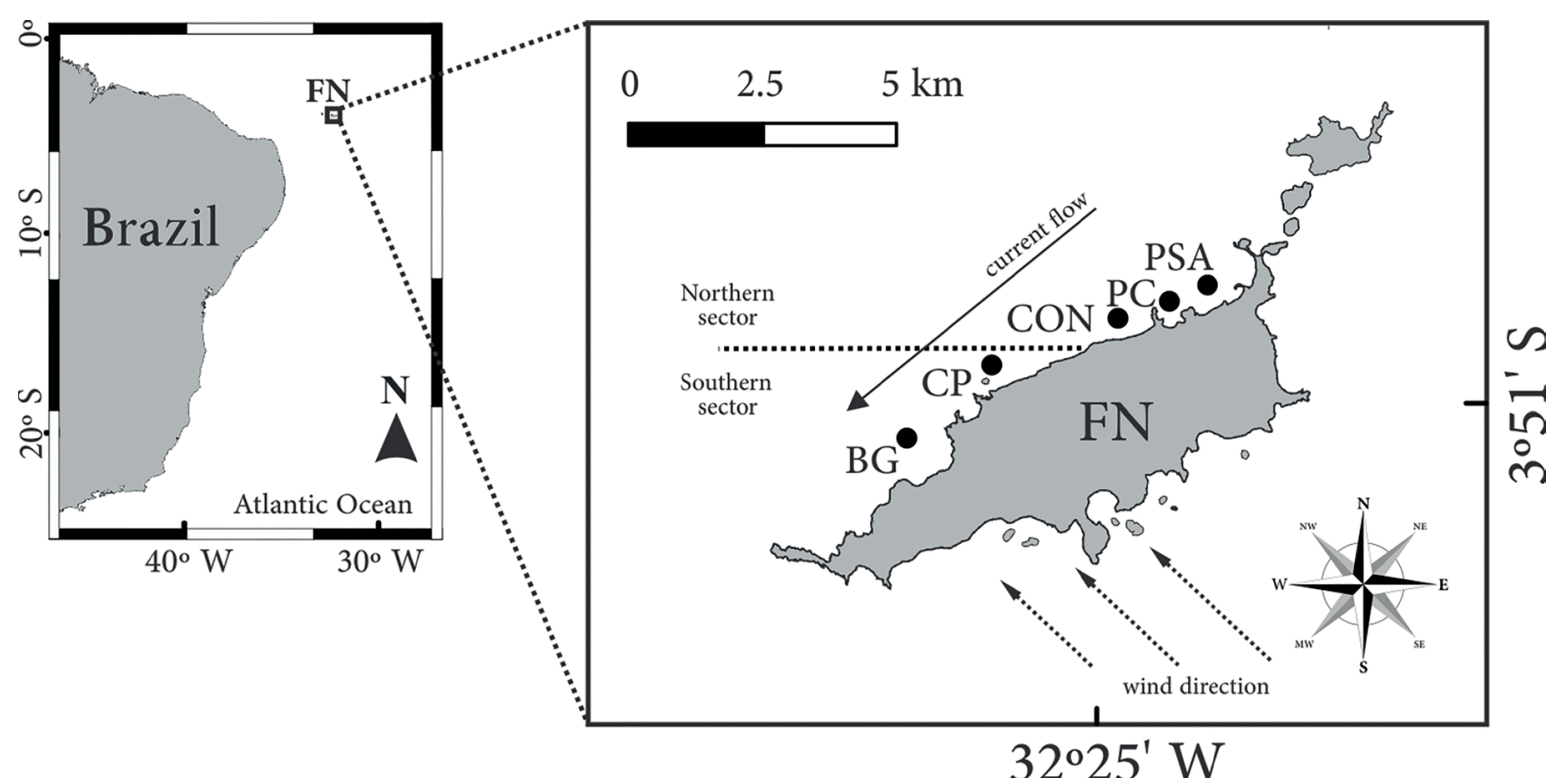

Figure 1. Fernando de Noronha archipelago (FN) $\left(03^{\circ} 51^{\prime} \mathrm{S}, 32^{\circ} 25^{\prime} \mathrm{W}\right)$ and the sampling stations: Porto de Santo Antônio (PSA), Praia do Cachorro (PC), Praia da Conceição (CON), Cacimba do Padre (CP) and Baía dos Golfinhos (BG).

northern part of the island, and Cacimba do Padre (CP) and Baía dos Golfinhos (BG), located in the southern part of the island (Figure 1). Local depth at the stations ranged from 2 to 30 meters, with an average depth of 16.6 meters. Diurnal samples were collected in 10 min subsurface horizontal hauls, with a standard plankton net $(300 \mu \mathrm{m}$ of mesh size and $60 \mathrm{~cm}$ mouth diameter), equipped with a calibrated flowmeter (General Oceanics $\left.{ }^{\circledR}\right)$. Subsequently, the samples were fixed with $4 \%$ formaldehyde, buffered with sodium tetraborate $\left(0.5 \mathrm{~g}^{*} \mathrm{~L}^{-1}\right)$, in accordance with Newell and Newell (1963).

\section{LABORATORIAL ANALYSIS}

In the laboratory, samples were analyzed in toto or in fractions of up to $1 / 4$ using a Motoda splitter (Omori and Ikeda, 1984). The specimens were identified under a stereomicroscope (Zeiss Discovery V8) and a microscope (Zeiss AxioScope A1), until the lowest possible taxonomic level, except for the infraorder Brachyura, using standard taxonomic literature and larval descriptions (mainly Pike and Williamson, 1958; Kurata, 1970; Dos Santos and Lindley, 2001; Fernandes et al., 2006).

\section{Data ANALYSis}

These abundance data (ind. $\mathrm{m}^{-3}$ ) were used to calculate the relative abundance (RA) of each taxon, the Shannon diversity (H') (Shannon, 1948) and evenness (Pielou, 1966). The results of the total abundance were log-transformed $(x+1)$ to improve the normality and homoscedasticity of the data, which were tested using Shapiro Wilk's and Levene's tests, respectively (Zar, 1999). After those tests, non-parametric methods, such as Kruskal-Wallis ANOVA and Mann-Whitney U-tests (Zar, 1999) were used to determine significant differences in larval abundance (taxa with more than $10 \%$ of relative abundance) between dry and rainy seasons, sampling years (2013 and 2014), stations (PSA, PC, CON, CP, BG) and northern sector (PSA, $\mathrm{PC}$ and $\mathrm{CP}$ pooled together) vs. southern sector (CP and $B G$ ). These analyses were carried out using the $R$ (v. 3.2.5) statistical environment (available at https://cran.r-project. org/) within the RStudio (v. 0.99) user interface (available at http://www.rstudio.com/).

The similarity between samples was calculated using the Bray-Curtis index (Bray and Curtis, 1957). The Bray-Curtis similarity matrix of $\log (\mathrm{X}+1)$-transformed abundance data was used to create MDS (multi-dimensional scaling) plots (Clarke and Warwick, 2001) to allow the visualization of the similarity between samples. To test for possible differences in community structure, PERMANOVA (Anderson, 2001) was carried out based on the abundance of decapods with relative abundance greater than $2 \%$. For the PERMANOVA, the same parameters were tested as for the univariate analyses (seasons, years, stations and sectors). SIMPER (Clarke and Warwick, 2001) was used to identify the taxa responsible for the separation between groups. All multivariate analyses were carried out using PRIMER with PERMANOVA (Anderson et al., 2008). 
All the larval stages analyzed (from penaeid, sergestid and caridean shrimps and brachyuran and anomuran crabs) were in the zoeal and decapodid stages, except the larvae of axiid, gebiid and stenopodid shrimps and lobster larvae (infraorder Achelata) wich were recorded only as zoeal stages. In the present study, we did not record decapods in the stage of nauplii or protozoea. The larval stage of decapodid/megalopae (settlement stage) was considered in the present work due to its representativeness in plankton samples, serving as an indicator in the contribution of the larval supply to the bentic community in the study area.

\section{RESULTS}

In this study 1,179 decapod larvae, belonging to 22 taxa, were identified. The Dendrobranchiata were represented by Penaeidae, Sergestidae and Luciferidae represented only by shrimp Belzebud faxoni (Borradaile, 1915), while the Pleocyemata were represented by 19 taxa: Stenopodidae, Pasiphaeidae, Palaemonidae, Alpheidae, Hippolytidae, Caridea (others), Axiidea, Axiidae, Callianassidae, Palinuridae, Scyllaridae, Anomura, Porcellanidae, Paguroidea, Clibanarius sp. Dana 1852, Gebiidea, Brachyura (zoeae), Brachyura (megalopae) and Decapoda (others). The Pasiphaeidae, Palaeomonidae, Hippolytidae, Caridea (others), Alpheidae, Clibanarius sp., Brachyura (zoeae) and Brachyura (megalopae) were present throughout the sampling seasons in both years (Table 1).

The total abundance of planktonic decapods during the study period showed a mean of $0.72 \pm 0.87$ ind. $\mathrm{m}^{-3}$. The most abundant groups were the zoeae-stage larvae of the hermit crab Clibanarius sp. (0.20 \pm 0.50 ind. $\mathrm{m}^{-3}, 27.19 \%$, all data) and zoeae of brachyuran crabs $\left(0.15 \pm 0.28\right.$ ind. $\mathrm{m}^{-3}$, $21.32 \%$, all data).

During the rainy season of 2013, the total abundance of decapod larvae presented $1.21 \pm 1.51$ ind. $\mathrm{m}^{-3}$ with a maximum of 1.20 ind. $\mathrm{m}^{-3}$. Zoeae of Brachyura and zoeae of Alpheidae were the most abundant, with a mean abundance of $0.46 \pm 0.50$ ind. $\mathrm{m}^{-3}(38.06 \%)$ and $0.22 \pm 0.40$ ind. $\mathrm{m}^{-3}(18.11 \%)$, respectively (Table 1$)$. During the dry season of 2013, the mean abundance of Decapoda was $0.85 \pm 0.79$ ind. $\mathrm{m}^{-3}$ with a maximum of 2.09 ind. $\mathrm{m}^{-3}$. Zoeastage larvae of the hermit crab Clibanarius sp. was the taxon with the highest average abundance $(0.53 \pm 0.88$ ind. $\mathrm{m}^{-3}, 62.48 \%$ ) among all the decapods. Alpheidae was the second most abundant group for the dry season of $2013\left(0.11 \pm 0.17\right.$ ind. $\left.\mathrm{m}^{-3}, 12.58 \%\right)$ (Table 1).

In the year 2014, during the rainy season, the total abundance of decapods was $0.54 \pm 0.35$ ind. $\mathrm{m}^{-3}$, with a maximum of 3.11 ind. $\mathrm{m}^{-3}$, Callianassidae $(0.14 \pm 0.11$ ind. $\left.\mathrm{m}^{-3}, 24.84 \%\right)$ and Caridea (others) $\left(0.08 \pm 0.13\right.$ ind. $\mathrm{m}^{-3}$, $13.93 \%$ ) being the most abundant taxa (Table 1). For the dry season of the same year, the total mean abundance of Decapoda was $0.15 \pm 0.16$ ind. $\mathrm{m}^{-3}$, with a maximum of 0.14 ind. $\mathrm{m}^{-3}$, Brachyura (zoeae) and Caridea (others) were the most abundant, with abundance values of $0.05 \pm 0.08$ ind. $\mathrm{m}^{-3}(36.89 \%)$ and $0.04 \pm 0.04$ ind. $\mathrm{m}^{-3}(24.94 \%)$, respectively (Table 1).

A clear tendency was observed for lower values of abundance at the northern stations (PSA, PC, CON), when compared to southern stations (CP, BG) (Figure 3). The station $\mathrm{CP}$ presented the highest abundance values among the sampling periods (Figure 2 and Figure 3 ).

The total numbers of decapods showed different tendencies of abundance, depending on the year and season of sampling (Figure 2). The southernmost stations presented high values of abundances of organisms during the rainy season of 2013 (at station CP) (Figure 2a), and in the dry season of the same year (BG and PC stations) (Figure 2b). During the year 2014 the northernmost stations presented high values of abundances in the rainy season (at station PC) (Figure 2c), and in the dry season (at station PSA) (Figure 2d).

The Shannon diversity index showed a mean value of $2.33 \pm 0.80$ bits.ind $^{-1}$ ranging from 0.15 bits.ind $^{-1}$ at the southernmost station of the island (BG) during the dry season of 2013 to 3.01 bits.ind $^{-1}$ at the northernmost station of the island (PSA), during the dry season of the same year. Evenness showed mean values of $0.78 \pm 0.20$ bits.ind ${ }^{1}$ ranging from 0.096 bits.ind $^{-1}$ at the southernmost station (BG) during the dry season of 2013 to 0.93 bits.ind $^{-1}$ at the northernmost station (CON) during the dry season of 2014. The different factors (season, year and station) did not display significant differences.

Regarding the temporal analysis, Clibanarius sp. presented higher abundances in 2013 than in 2014 ( $p=0.012$; Mann-Whitney; Figure 4a). The spatial analysis showed that in relation to the sectors (northern and southern) Clibanarius sp. presented higher abundances in the Southern sector ( $p=0.026$; Mann-Whitney, Figure $4 b$ ). When comparing the two seasons, Callianassidae showed the highest relative abundance during the rainy season ( $p=0.002$; Mann-Whitney; Figure 4c). 


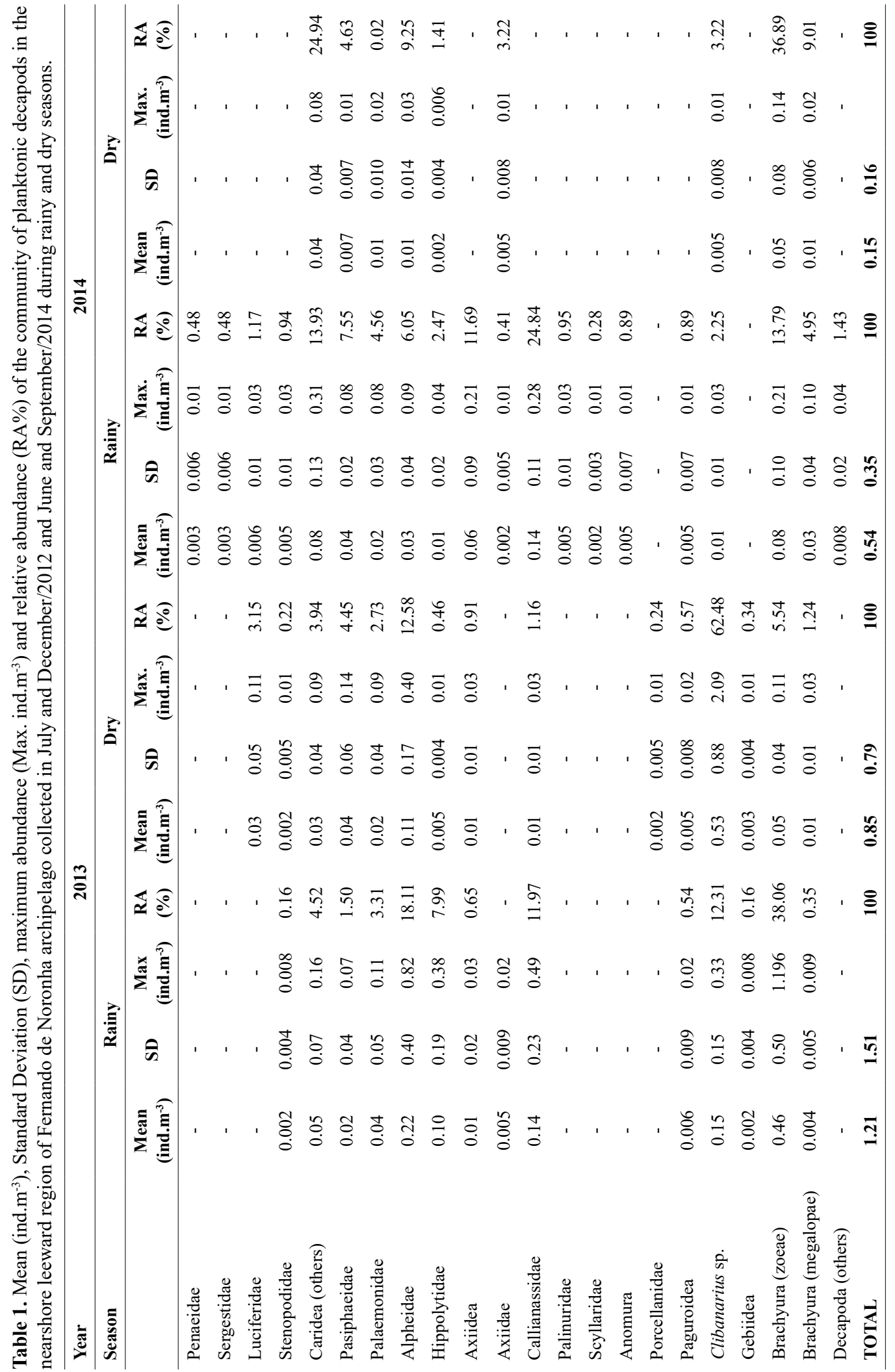



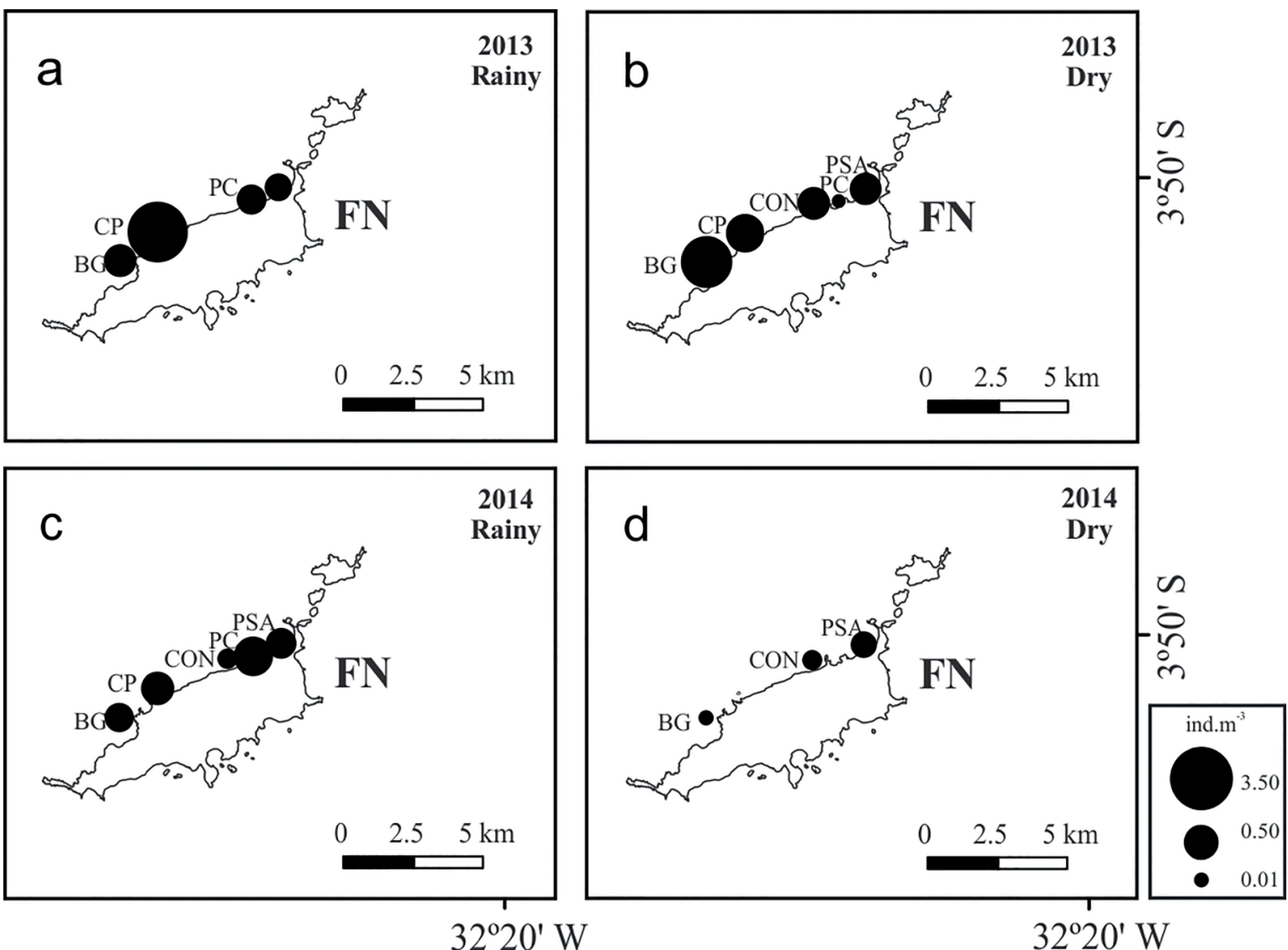

Figure 2. Spatio-temporal distribution of the total abundance of decapod larvae (ind. $\mathrm{m}^{-3}$ ) sampled on the leeward coast of the Fernando de Noronha archipelago during the rainy and dry seasons of 2013 and 2014. The area of the circles is proportional to the abundance of decapod larvae at each station. Sampling stations: Porto de Santo Antônio (PSA), Praia do Cachorro (PC), Praia da Conceição (CON), Cacimba do Padre (CP) and Baía dos Golfinhos (BG). a) Rainy season, July 2013. b) Dry season, December 2013. c) Rainy season, June 2014. d) Dry season, November 2014.

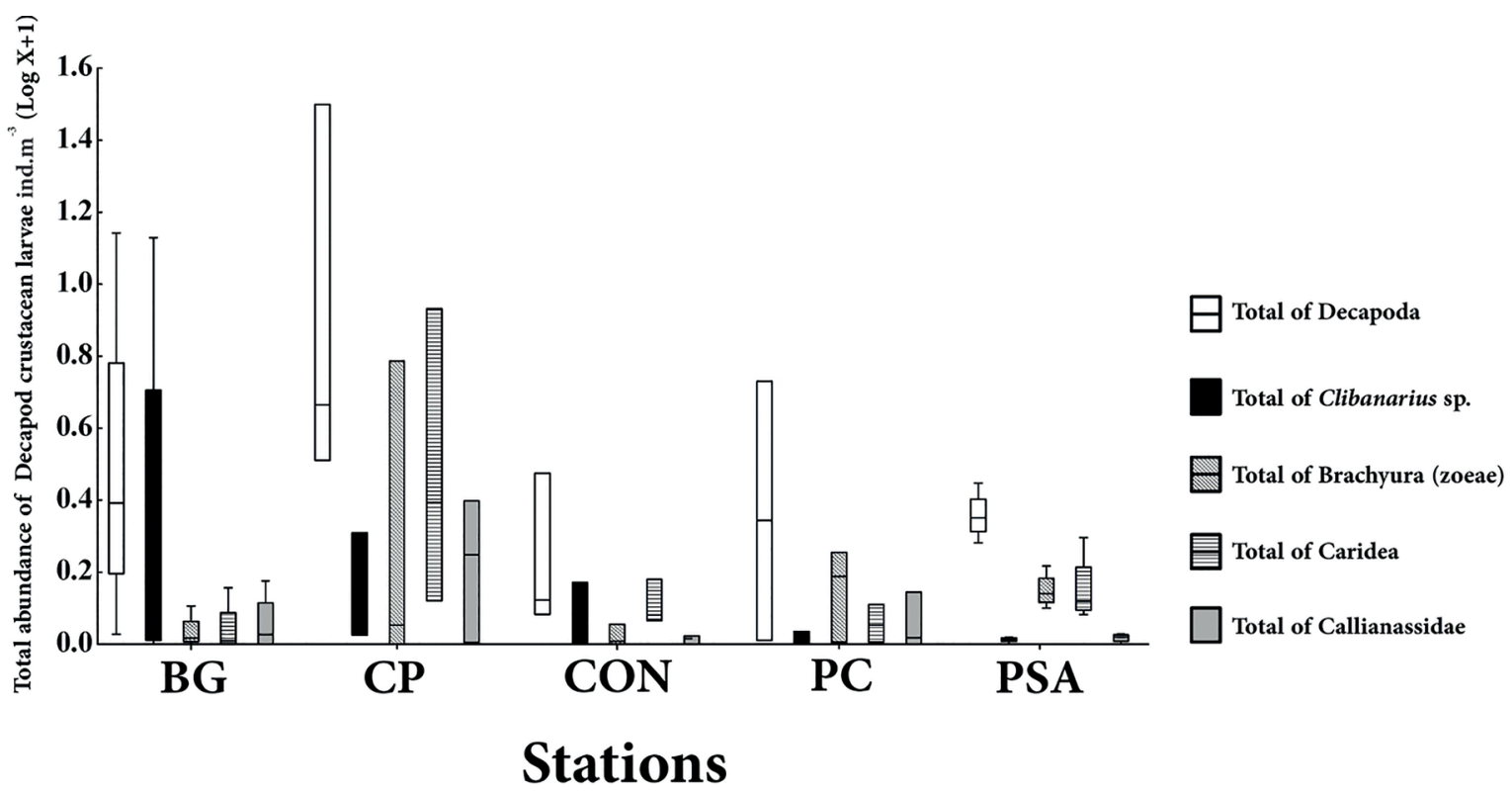

Figure 3. Box-Plot (mean and quartile) of the transformed $\log (\mathrm{x}+1)$ of the most abundant decapods $\left(\right.$ ind. $\left.\mathrm{m}^{-3}\right)$ from the plankton community in the nearshore leeward coast of the Fernando de Noronha archipelago in 2013 and 2014. Sampling stations: Baía dos Golfinhos (BG), Cacimba do Padre (CP), Praia da Conceição (CON), Praia do Cachorro (PC) and Porto de Santo Antônio (PSA). 

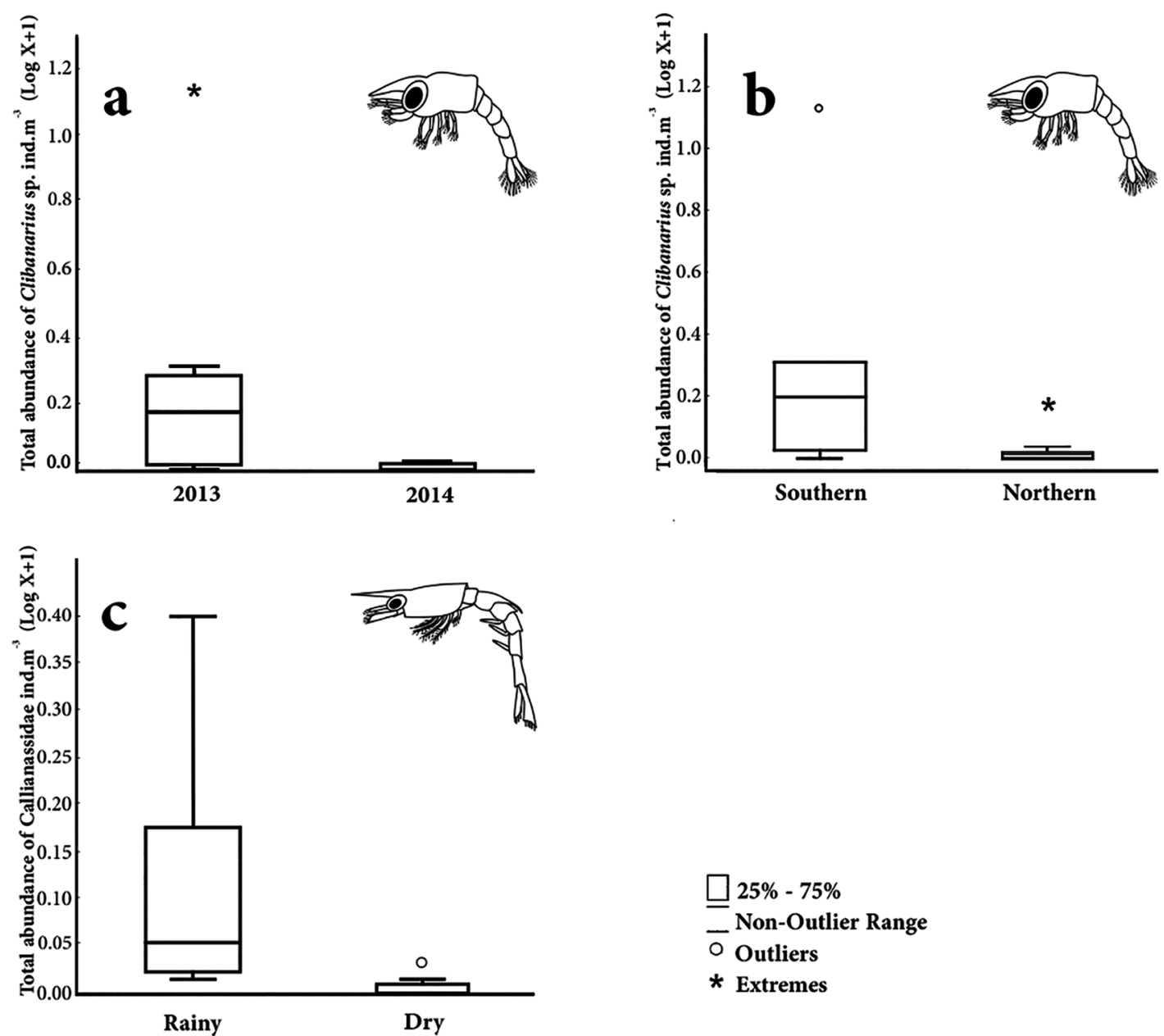

Figure 4. Box-Plot (mean and quartiles) representing the $\log (x+1)$ of total abundance of decapod larvae (ind. $\left.m^{-3}\right)$ of the plankton community in the nearshore leeward area of the Fernando de Noronha archipelago: a) interannual variation of zoeae of Clibanarius sp. b) variation between sectors of zoeae of Clibanarius sp., and c) seasonal variation of zoeae of Callianassidae.

The multidimensional scaling (MDS) plots created for the communities of decapods showed a clear distinction between stations (Figure 5c) and between years (Figure 5d). These differences in community structure between years and between stations were confirmed by PERMANOVA, that revealed differences in planktonic decapods between 2013 and $2014(p=0.04)$ and also between sampling stations $(p=0.03)$ (Table 2). The sampling stations BG-Baía dos Golfinhos ( $p=0.03)$, CP-Cacimba do Padre $(p=0.03)$ and CON-Praia da Conceição $(p=0.02)$ presented differences when compared to PSA-Porto de Santo Antônio (Table 3). The SIMPER test showed a mean dissimilarity of 77.2 between years, and between stations BG $v s$. PSA (79.36), CP vs. PSA (75.5), PSA vs. CON (66.5). The main groups responsible for the dissimilarity among the factors were Clibanarius sp., Brachyuran zoeae, Alpheidae, Callianassidae and Caridea (Table 4).

The Simper test showed an average similarity of 70.11 in the northern sector and 45.71 in the southern sector. The percentage of species composition showed a mean similarity of 19.86 during the rainy seasons and 31.23 during the dry seasons. The main groups responsible for the similarity among the factors were Brachyura (zoeae), Clibanarius sp., Callianassidae, Alpheidae and Pasiphaeidae (Table 5). 


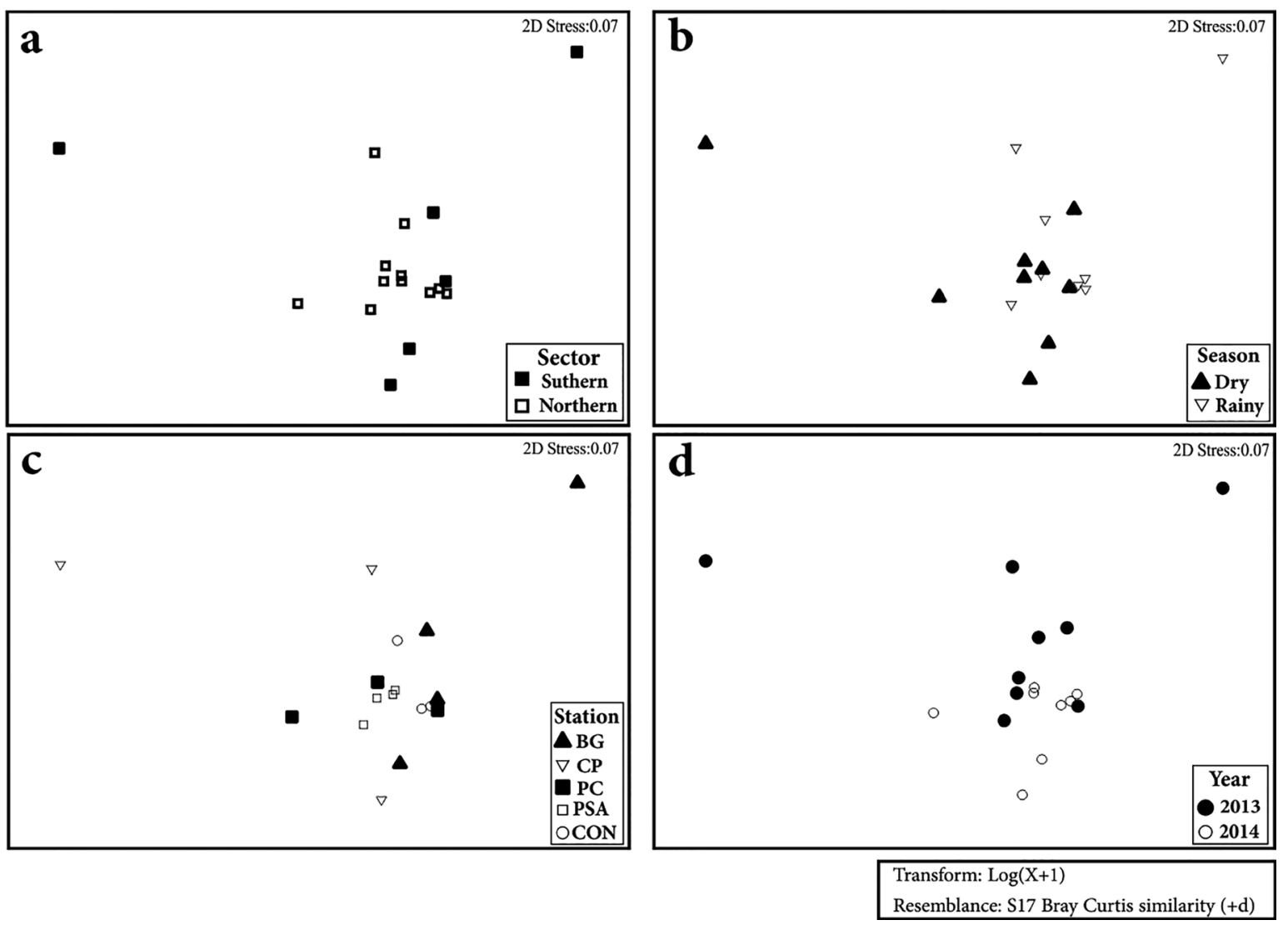

Figure 5. MDS ordination analysis (multidimensional scaling), to show the similarity between the factors based on the abundance of 22 planktonic decapod taxa; a. sector (northern and southern); b. season (rainy and dry); c. sampling stations: Baía dos Golfinhos (BG), Cacimba do Padre (CP), Praia do Cachorro (PC), Porto de Santo Antônio (PSA), Praia da Conceição (CON); d. year (2013 and 2014).

Table 2. PERMANOVA results of the planktonic decapod community structure in relation to the factors "year" (2013, 2014), "season" (rainy and dry), sector (northern and southern) and "station" (PSA, PC, CON, CP, BG) on the Fernando de Noronha archipelago.

\begin{tabular}{lcccc}
\hline Factor & df & MS & Pseudo-F & $\boldsymbol{p}$ \\
\hline Year & 1 & 788.82 & 2.2595 & $\mathbf{0 . 0 4}$ \\
Season & 1 & 674.07 & 1.8894 & 0.09 \\
Sector & 1 & 649.43 & 1.812 & 0.10 \\
Station & 4 & 558.07 & 1.7654 & $\mathbf{0 . 0 3}$ \\
\hline
\end{tabular}

Table 3. Pairwise PERMANOVA of the planktonic decapod community structure between stations Porto de Santo Antônio (PSA), Praia da Conceição (CON), Cacimba do Padre (CP) and Baía dos Golfinhos (BG) on the Fernando de Noronha archipelago.

\begin{tabular}{lcc}
\hline Groups & $\mathbf{t}$ & $\boldsymbol{p}$ \\
\hline BG, PSA & 1.5609 & $\mathbf{0 . 0 3}$ \\
CP, PSA & 1.6857 & $\mathbf{0 . 0 3}$ \\
PSA, CON & 1.5923 & $\mathbf{0 . 0 2}$ \\
\hline
\end{tabular}

The similarity between the sectors and seasons was highlighted by the multidimensional scaling (MDS) (Figure 5a, $5 b)$.

\section{DISCUSSION}

This study revealed tendencies of distribution (temporal-spatial) and composition of planktonic decapods during the rainy and dry seasons of 2013 and 2014 in the nearshore leeward area of the Fernando de Noronha archipelago. A higher abundance of planktonic decapods was found at the southernmost stations of the island, however there were no great variations among stations in relation to taxonomic composition. Studies on abundance of planktonic decapods were performed in the oceanic waters off Fernando de Noronha by Lira et al. (2014). However, these studies were conducted far away from the coast, and none of these previous studies investigated the distribution of decapods along the nearshore leeward area of the archipelago. 
Table 4. Decapoda larvae contribution $(<80 \%)$ to the mean dissimilarity by year $(2013$ and 2014$)$ and sampling station (PSA, PC, CON, CP, BG) in the leeward coast of the Fernando de Noronha archipelago, as determined by SIMPER analysis.

\begin{tabular}{|c|c|c|c|}
\hline Taxa & $\begin{array}{c}\text { Mean } \\
\text { dissimilarity }\end{array}$ & $\begin{array}{c}\text { Contribution } \\
(\%)\end{array}$ & $\begin{array}{c}\text { Cumulative } \\
\text { value }(\%)\end{array}$ \\
\hline Years 2013 - 2014 & 77.23 & & \\
\hline Clibanarius sp. & & 25.98 & 25.98 \\
\hline Brachyura (zoea) & & 20.48 & 46.46 \\
\hline Alpheidae & & 11.8 & 58.26 \\
\hline Callianassidae & & 11.34 & 69.6 \\
\hline Caridea & & 8.14 & 77.74 \\
\hline Stations BG - PSA & 79.36 & & \\
\hline Clibanarius sp. & & 33.89 & 33.89 \\
\hline Brachyura (zoeae) & & 20.85 & 54.74 \\
\hline Callianassidae & & 9.46 & 64.2 \\
\hline Caridea & & 8.47 & 72.67 \\
\hline Stations CP - PSA & 75.53 & & \\
\hline Alpheidae & & 21.04 & 21.04 \\
\hline Brachyura (zoeae) & & 19.78 & 40.83 \\
\hline Callianassidae & & 16.65 & 57.48 \\
\hline Clibanarius sp. & & 14.4 & 71.88 \\
\hline Stations PSA - CON & 66.5 & & \\
\hline Brachyura (zoeae) & & 36.25 & 36.25 \\
\hline Clibanarius sp. & & 11.95 & 48.2 \\
\hline Caridea & & 10.67 & 58.86 \\
\hline Pasiphaeidae & & 9.46 & 68.32 \\
\hline Alpheidae & & 7.77 & 76.09 \\
\hline
\end{tabular}

\section{TAXON-SPECIFIC DISTRIBUTION PATTERNS}

The larvae of benthic species represent the larger part of the planktonic decapods recorded in this study (such as the larvae of Brachyura, Clibanarius sp., Callianassidae and Alpheidae). This fact shows the great contribution of meroplankton in the region, an expected feature, since the coastal region of islands provide ecological niches suitable for larval settlement and adult development (evidenced by the presence of decapodids in plankton samples), as has been seen for other island environments, such as that of the island of Gran Canaria, in the North Atlantic Ocean (Landeira et al., 2013).

Larvae zoea of the hermit crab Clibanarius sp. presented the highest mean abundances among planktonic decapods. Their main abundance peak was during December 2013 (dry season). The high abundance of early-stage larvae of this genus may be the result of a recent spawning event, which greatly increased the abundance of decapods at the southern stations during the dry season of 2013. Adults of this genus recorded at FN are Clibanarius antillensis
Stimpson, 1859 (Alves et al., 2008) and Clibanarius tricolor (Gibbes, 1850) (Coelho, 1967/1969; Coelho and Ramos, 1972; Coelho and Ramos-Porto, 1986; Fausto-Filho, 1974; Alves et al., 2008). C. antillensis has continuous reproduction, concentrated between November and March (austral summer) in the subtropical region of Brazil (São Sebastião/ SP) (Turra and Leite, 1999) and in the dry and hot months of October to December in tropical Brazil (Areia Branca/RN) (Bezerra, personal communication ${ }^{* 1}$ ), in agreement with the high larval abundances found in this study in December.

Adults of both of species (C. antillensis and C. tricolor) occur in seaweed beds, on rocks or reefs, inside rocks, under rocks on sandy-muddy bottoms, in intertidal pools and sublittoral zones (Alves et al., 2008) and the area sampled in this study covered many of these habitats. The importance of the spawning of Clibanarius sp. was evidenced by the large contribution of this taxon in the dissimilarity between the years 2013 and 2014; it was also one of the three main groups responsible for the dissimilarity between the southernmost and northernmost stations (BG, $\mathrm{CP}$ and CON), together with brachyuran zoeae and Alpheidae.

*1Personal communication of Luis Ernesto Arruda Bezerra, on May 24, 2017, received by electronic mail. 
Table 5. Contribution of decapod larvae to the mean similarity $(<80 \%)$ in the sectors (northern and southern) and during the seasons (rainy and dry) of 2013 and 2014, in the nearshore leeward area of Fernando de Noronha archipelago, as determined by SIMPER analysis.

\begin{tabular}{|c|c|c|c|}
\hline Taxa & $\begin{array}{c}\text { Mean } \\
\text { similarity }\end{array}$ & $\begin{array}{c}\text { Contribution } \\
(\%)\end{array}$ & $\begin{array}{c}\text { Cumulative } \\
\text { value (\%) }\end{array}$ \\
\hline Northern & 70.11 & & \\
\hline $\begin{array}{l}\text { Brachyura } \\
\text { (zoeae) }\end{array}$ & & 16.69 & 16.69 \\
\hline Alpheidae & & 15.3 & 31.99 \\
\hline Pasiphaeidae & & 13.8 & 45.79 \\
\hline Palaemonidae & & 12.3 & 58.09 \\
\hline Southern & 45.71 & & \\
\hline Clibanarius sp. & & 26.05 & 26.05 \\
\hline $\begin{array}{l}\text { Brachyura } \\
\text { (zoeae) }\end{array}$ & & 21.46 & 47.51 \\
\hline $\begin{array}{l}\text { Brachyura } \\
\text { (megalopae) }\end{array}$ & & 13.65 & 61.16 \\
\hline Callianassidae & & 13.6 & 74.75 \\
\hline Rainy & 19.86 & & \\
\hline $\begin{array}{l}\text { Brachyura } \\
\text { (zoeae) }\end{array}$ & & 28.56 & 28.56 \\
\hline Clibanarius sp. & & 18.13 & 46.69 \\
\hline $\begin{array}{l}\text { Caridea } \\
\text { (others) }\end{array}$ & & 16.99 & 63.68 \\
\hline Alpheidae & & 10.79 & 74.48 \\
\hline Dry & 31.23 & & \\
\hline $\begin{array}{l}\text { Brachyura } \\
\text { (zoeae) }\end{array}$ & & 34.32 & 34.32 \\
\hline Callianassidae & & 23.84 & 58.17 \\
\hline Alpheidae & & 9.09 & 67.25 \\
\hline Pasiphaeidae & & 7.24 & 74.49 \\
\hline
\end{tabular}

Brachyuran crab larvae in early stages (zoeae) were present in most samples, being dominant at some stations. At the St. Peter and St. Paul's archipelago (Tropical Atlantic), brachyuran zoeae were also the most abundant group among the Decapoda (Díaz et al., 2009; Brandão et al., 2013), and their relative abundance revealed that they were even more abundant than copepods during the rainy season, central bay of St. Peter and St. Paul's (Díaz et al., 2009).

The present study also highlights the role of the larvae of burrowing shrimps of the family Callianassidae, their major contributions occurring during the rainy season of 2014. The only adult specie recorded on Fernando de Noronha island is Neocallichirus grandimana (Gibbes, 1850) (Alves et al., 2008). However, nothing is known about the reproduction of this specie, and little is known about the reproductive biology of tropical burrowing shrimps in general (Hernáez et al., 2012). Some reports that have addressed the reproductive season of Calianassidea of the same subfamily (Callichirinae) as the genus found on $\mathrm{FN}$, point to the existence of reproductive peaks during the rainy months (Felder, 2002; Hernáez et al., 2012), suggesting a possible relationship with the decrease in salinity (Hernáez et al., 2012).

ECOLOGICAL INDEXES, ABUNDANCE AND TAXONOMIC COMPOSITION

In the dry season of 2013, the low diversity recorded in southern stations of the island (BG), occurred due to the huge abundance of Clibanarius sp., while northern stations (PSA) showed greater diversity due to increased richness of planktonic decapod species during the same period. The diversity observed in the current study was very similar to that reported by Landeira et al. (2013) in waters close to the Canary Islands. Despite the differences found between the northern and southern sectors, the values of equitability showed that the community structure does not suffer from large fluctuations, being considered homogeneous during the study period.

In general, the abundance of planktonic decapods recorded off Fernando de Noronha presented much smaller values compared to the inlet coastal regions of St. Peter and St. Paul's archipelago (e.g. Díaz et al., 2009; Koettker et al., 2010 and Brandão et al., 2013), the open area of this archipelago (Brandão et al., 2013) and alongshore of the Canary Islands (Landeira et al., 2013). The abundance recorded in the present study was like those recorded for the open area around St. Peter and St. Paul's (Koettker et al., 2010), being higher than the values recorded by Landeira et al. $(2009,2010)$ in waters around the Canary Islands and Torres et al. (2013) in the Balearic Sea.

Despite the species Lucifer typus H. Milne Edwards, 1837 being recorded at insular environments in the Atlantic Ocean, like Canary Islands (Landeira et al., 2009, 2010) and St. Peter and St. Paul's (Díaz et al., 2009), this common luciferid shrimp was not recorded herein. The family Luciferidae was represented only by Belzebud faxoni, as this species occurs in waters closer to coastal regions, whereas L. typus occurs in open oceanic areas. Pandalidae is a family recorded by several authors in the Atlantic Ocean (e. g. Paula, 1987; Torres et al., 2013) including insular environments (Landeira et al., 2009, 2010, 
2013; Koettker et al., 2010; Brandão et al., 2013), however this family was not recorded in the present study.

Stenopodidae was recorded in both years and seasons (except dry season of 2014), being common in our surveys. However, none Stenopodidea were recorded in previous reports from other Tropical Atlantic islands (Koettker et al., 2010, Brandão et al., 2013). Larvae of anomuran crabs were common in the leeward coast of FN during all the period of sampling, but they were absent around St. Peter and St. Paul (Koettker et al., 2010; Brandão et al., 2013).

Overall, the taxonomic composition recorded in the present study was similar to that recorded by Landeira et al. $(2010,2013)$ off Canary Islands, including the presence of the rare planktonic larvae of the caridean shrimp Amphionides reynaudii (H. Milne Edwards, 1833), recorded from the Tropical Atlantic by Lira et al. (2017), in the Fernando de Noronha archipelago.

\section{RELEVANCE OF GEOGRAPHICAL FEATURES AND POSSIBLE RETENTION PHENOMENA}

The tendencies in spatial distribution showed an increasing gradient from the northernmost stations towards the southern stations, with the southern sector ( $\mathrm{CP}$ and $\mathrm{BG})$ presenting the highest abundances of decapod larvae. The greater abundance of decapods recorded to the south of the oceanic islands, due to these being more disturbed areas ("Island mass effect") was also observed by Landeira et al. (2010), when he studied two transects (north and south) off the Canary Islands.

This general pattern can be related to local hydrodynamics, as the predominant surface currents of the leeward part of the island usually flow from Porto de Santo Antônio to Baía dos Golfinhos (from northeast to southwest), and the current could thus carry the larvae from the north of the island and accumulate them in the south (Lira et al., 2014; Lira, personal communication ${ }^{* 2}$ ), highlighting the larval Island effect. However, there are still no published detailed data on the dynamics of currents in the nearshore leeward area of the Fernando de Noronha archipelago.

Large neritic larval abundances at coastal stations around oceanic islands are common and may suggest a larval retention (Brandão et al., 2012, 2013; Landeira et al., 2013) which ensures the maintenance of larvae near their areas of origin (Mcconaugha, 1992; Landeira et al., 2009).
ECOSYSTEM PROCESSES AFFECTING THE PLANKTONIC DECAPODS

During our study, the Porto de Santo Antônio station, sheltered from currents, presented the highest concentration of ammonium $\left(\mathrm{NH}_{4}^{+}\right)$, nitrate $\left(\mathrm{NO}_{3}^{-}\right)$and nitrite $\left(\mathrm{NO}_{2}^{-}\right)$ in 2014, particularly in the rainy season (Assunção et al., 2016). These results could be due to the sheltered nature of the port (hydrodynamics), or to the input of sewage from terrestrial sources (tourism), or from harbor activity (sewage from boats). Further, this peak in nutrients, albeit at very low concentrations, could be due to a decrease in phytoplankton (Dugdale, 1967). The decrease in the phytoplankton community affects the zooplankton community (secondary consumers) directly, causing their decline (Costlow and Bookhout, 1959; Anger and Dawirs, 1981; Emmerson, 1984; Anger, 2001).

Despite the higher nutrient values found at the Porto de Santo Antônio station, the amounts registered were within the expected values for oligotrophic regions (Assunção et al., 2016). It is likely that the region experiences nutrient pulses over time, as the archipelago has a large number of nesting areas for sea birds, which produce a large amount of guano fertilizer (Bosman and Hockey, 1986; Polis et al., 1997). This guano can be transported by rain-water or washed into the sea by waves and high swell (Polis et al., 1997), thus explaining the sudden increase in the nutrient concentration in the rainy season (Assunção et al., 2016). Other general factors that may be highlighted to explain the increase of nutrients are the sediment resuspension with the intense swell and an increment of the stools and vomiting of spinner dolphin populations that inhabit the Baía dos Golfinhos (Sazima et al., 2003). We observed a general trend of higher abundances of decapods during the rainy season in both years, coinciding with the highest levels of salinity and lower temperatures in the surface layer (Assunção et al., 2016). This pattern has also been registered for the St. Peter and St. Paul archipelago (Brandão et al., 2013).

\section{CONCLUSION}

This study is one of the few that addresses the distribution, variation and composition of decapods in coastal areas of the oceanic islands of the equatorial Atlantic Ocean, considering seasons and years. Finally, the north-south

\footnotetext{
*2Personal communication of Simone Maria de Albuquerque Lira, on December 7, 2016.
} 
abundance increasing trend indicates a possible larval retention, which is probably related to the current dynamics in the coastal region of the archipelago. However, further studies are necessary to better elucidate the patterns of alongshore transport and retention in this unique oceanic hotspot.

\section{ACKNOWLEDGEMENTS}

We wish to express our thanks to the Conselho Nacional de Desenvolvimento Científico e Tecnológico (CNPq) who conceded the first author's Scientific Initiation scholarship and the last author's PhD Scholarship, and to the CARECOS Project - funded by the Fundação de Amparo à Ciência e Tecnologia de Pernambuco - FACEPE no APQ0074-1.08/11 and the Fundação de Amparo à Pesquisa do Estado de São Paulo - FAPESP 2011/5052-0. We wish also to thank the Projeto Golfinho Rotador for their support.

\section{REFERENCES}

ALVES, M. L., RAMOS-PORTO, M. \& VIANA, G. F. S. 1881. Checklist of the Decapods (Crustacea) from the Fernando de Noronha Archipelago, Brazil. Zootaxa, 43-68.

ANDERSON, M. J. 2001. A new method for non-parametric multivariate analysis of variance. Austral Ecology, 26, 32-46.

ANDERSON, M. J., GORLEY, R. N. \& CLARKE, K. R. 2008. PERMANOVA+ for PRIMER, Plymouth, PRIMER-E.

ANGER, K. 2001. The biology of decapod crustacean larvae, Lisse, AA Balkema Publishers.

ANGER, K. \& DAWIRS, R. R. 1981. Influence of starvation on the larval development of Hyas araneus (Decapoda, Majidae). Helgoländer Meeresuntersuchungen, 34, 287-311.

ASSUNÇÃO, R. V., SILVA, A. C., MARTINS, J. \& MONTES, M. F. 2016. Spatial-Temporal Variability of the Thermohaline Properties in the Coastal Region of Fernando de Noronha Archipelago, Brazil. Journal of Coastal Research, 75, 512-516.

BOLTOVSKOY, D. 1981. Atlas del zooplancton del Atlántico sudoccidental y métodos de trabajo con el zooplancton marino, Mar del Plata, Instituto Nacional de Investigación y Desarrollo Pesquero.

BOSMAN, A. L. \& HOCKEY, P. A. R. 1986. Seabird guano as a determinant of rocky intertidal community structure. Marine Ecology Progress Series, 32, 247-257.

BRANDÃO, M. C., KOETTKER, A. G. \& FREIRE, A. S. 2013. Abundance and composition of decapod larvae at Saint Paul's Rocks (equatorial Atlantic). Marine Ecology, 34, 171-185.

BRANDÃO, M. C., KOETTKER, A. G. \& FREIRE, A. S. 2012. Distribution of Decapod larvae in the surface layer of an isolated equatorial oceanic archipelago: the cases of benthic Grapsus grapsus (Brachyura: Grapsidae) and pelagic Sergestes edwardsi (Dendrobranchiata: Sergestidae). Helgoland Marine Research, 67, 155-165.

BRAY, J. R. \& CURTIS, J. T. 1957. An ordination of the upland forest communities of southern Wisconsin. Ecological Monographs, 27, 325-349.
CLARKE, K. R. \& WARWICK, R. M. 2001. A further biodiversity index applicable to species lists: variation in taxonomic distinctness. Marine Ecology Progress Series, 216, 265-278.

COSTLOW, JD Jr. \& BOOKHOUT, C. G. 1959. The larval development of Callinectes sapidus Rathbun reared in the laboratory. Biological Bulletin, 116, 373-396.

COELHO, P. A. 1967/1969. A distribuição dos crustáceos decápodos reptantes do Norte do Brasil. Trabalho de Oceanografia da Universidade Federal de Pernambuco, 9, 223-238.

COELHO, P. A. \& RAMOS, M. A. 1972. A constituição e a distribuição da fauna de decápodos do litoral leste da América do Sul entre as latitudes de $5^{\circ} \mathrm{N}$ e $39^{\circ} \mathrm{S}$. Trabalho de Oceanografia da Universidade Federal de Pernambuco, 13,133-236.

COELHO, P. A. \& RAMOS-PORTO, M. 1986. Sinopse dos crustáceos decápodos brasileiros (famílias Callianassidae, Callianideidae, Upogebiidae, Parapaguridae, Paguridae, Diogenidae). Trabalho de Oceanografia da Universidade Federal de Pernambuco, 19, 27-53.

DE ALMEIDA, F. F. M. 1955. Geologia e petrologia do Arquipélago de Fernando de Noronha. Rio de Janeiro: Serviço Gráfico do Instituto Brasileiro de Geografia e Estatística.

DE GRAVE, S., PENTCHEFF, N. D., AHYONG, S. T., CHAN, T. Y., CRANDALL, K. A., DWORSCHAK, P. C., FELDER, D. L., FELDMANN, R. M., FRANSEN, C. H. J. M., GOULDING, L. Y. D., LEMAITRE, R., LOW, M. E. Y., MARTIN, J. W., NG, P. K. L., SCHWEITZER, C. E., TAN, S. H., TSHUDY, D. \& WETZER, R. 2009. A classification of living and fossil genera of Decapod Crustaceans. Raffles Bulletin of Zoology, 21, 1-109.

DÍAZ, X. F. G., GUSMÃO, L. M. O. \& NEUMANN-LEITÃO, S. 2009. Biodiversidade e dinâmica espaço-temporal do zooplâncton. In: HAZIN F. (Ed), O Arquipélago de São Pedro e São Paulo: 10 anos de Estação Científica. 1a ed. Brasília: Comissão Interministerial Para os Recursos do Mar. 139-149.

DOS SANTOS, A. \& LINDLEY, J. 2001. Crustacea Decapoda: Larvae II. Dendrobranchiata (Aristeidae, Benthesicymidae, Penaeidae, Solenoceridae, Sicyonidae, Sergestidae, and Luciferidae). ICES Fiches d'Identification du Zooplancton, 186, 1-9.

DOTY, M. S. \& OGURI, M. 1956. The Island Mass Effect. ICES Journal of Marine Science, 22, 33-37.

DUGDALE, R. C. 1967. Nutrient limitation in the sea: dynamics, identification and significance. Limnology and Oceanography, 12, 685-695.

EMMERSON, W. D. 1984. Predation and energetics of Penaeus indicus (Decapoda: Penaeidae) larvae feeding on Brachionus plicatilis and Artemia nauplii. Aquaculture, 38, 201-209.

FAUSTO FILHO, J. 1974. Stomatopod and decapod crustaceans of the Archipelago of Fernando de Noronha, Northeast Brazil. Arquivos de Ciências do Mar, 14, 1-35.

FELDER, D. L. 2002. Ventrally sclerotized members of Lepidophthalmus (Crustacea: Decapoda: Callianassidae) from the eastern Pacific. Annalen des Naturhistorischen Museums in Wien, 104, 429-442.

FERNANDES, L. D. A., ALMEIDA, E. V., PEIXOTO, B. J. F. S. \& SOUZA, M. F. 2006. Larvas de Decapoda. In: BONECKER, S. L. C. (eds.), Atlas de zooplâncton da região central da Zona Econômica Exclusiva brasileira: Série Livro/Documentos REVIZEE Score Central. Rio de Janeiro: Museu Nacional. 101-163.

GIBSON, R. N. 2003. Go with the flow: tidal migration in marine animals. In: Migrations and Dispersal of Marine Organisms. Dordrecht: Springer Netherlands. 153-161. 
GOVE, J. M., McMANUS, M. A., NEUHEIMER, A. B., POLOVINA, J. J., DRAZEN, J. C., SMITH, C. R., MERRIFIELD, M. A., FRIEDLANDER, A. M., EHSES, J. S., YOUNG, C. W., DILLON, A. K. \& WILLIAMS, G. J. 2016. Near-island biological hotspots in barren ocean basins. $\mathrm{Na}$ ture Communications, 7, 10581.

HERNÁEZ, P., VILLEGAS-JIMÉZES, E., VILLALOBOSROJAS, F. \& WEHRTMANN, I. S. 2012. Reproductive biology of the ghost shrimp Lepidophthalmus bocourti (A. Milne-Edwards, 1870) (Decapoda: Axiidea: Callianassidae): A tropical species with a seasonal reproduction. Marine Biology Research, 8, 635-643.

HERNÁNDEZ-LEÓN, S. 1991. Accumulation of mesozooplankton in a wake area as a causative mechanism of the "islandmass effect". Marine Biology, 109, 141-147.

KOETTKER, A. G., FREIRE, A. S. \& SUMIDA, P. Y. G. 2010. Temporal, diel and spatial variability of decapod larvae from St Paul's Rocks, an equatorial oceanic island of Brazil. Journal of the Marine Biological Association of the United Kingdom, 90, 1227-1239.

KOETTKER, A. G. \& FREIRE, A. S. 2006. Spatial and temporal distribution of decapod larvae in the subtropical waters of the Arvoredo archipelago, SC, Brazil. Iheringia. Série Zoologia, 96, 31-40.

KURATA, H. 1970. Studies on the life histories of decapod Crustacea of Georgia. Sapelo Island: University of Georgia, Marine Institute.

LANDEIRA, J. M., LOZANO-SOLDEVILLA, F. \& HERNÁNDEZ-LEÓN, S. 2013. Temporal and alongshore distribution of decapod larvae in the oceanic island of Gran Canaria (NW Africa). Journal of Plankton Research, 35, 309-322.

LANDEIRA, J. M., LOZANO-SOLDEVILLA, F., HERNÁNDEZ-LEÓN, S. \& BARTON, E. D. 2010. Spatial variability of planktonic invertebrate larvae in the Canary Islands area. Journal of the Marine Biological Association of the United Kingdom, 90, 1217-1225.

LANDEIRA, J. M., LOZANO-SOLDEVILLA, F., HERNÁNDEZ-LEÓN, S. \& BARTON, E. D. 2009. Horizontal distribution of invertebrate larvae around the oceanic island of Gran Canaria: the effect of mesoscale variability. Scientia Marina, 73,761-771.

LE BORGNE, R., DANDONNEAU, Y. \& LEMASSON, L. 1985. The problem of the island mass effect on chlorophyll and zooplankton standing crops around Mare (Loyalty Islands) and New Caledonia. Bulletin of Marine Science, 37, 450-459.

LIRA, S. M. A., SANTANA, C. S., LIMA, C. D. M., MONTES, M. J. F. \& SCHWAMBORN, R. 2017. New records of larvae of Cerataspis monstrosa and Amphionides reynaudii (Crustacea: Decapoda) from the western tropical Atlantic. Zootaxa, 4237, 335-346.

LIRA, S. M. A., De SANTANA, C. S., SCHWAMBORN, R. 2018. First record of Naushonia sp. (Decapoda: Laomediidae) larva from the Equatorial Atlantic. Zootaxa, 4387, 183-194

LIRA, S. M. A., TEIXEIRA, I. A., LIMA, C. D. M., SANTOS, G. S., LEITÃO, S. N. \& SCHWANBORN, R. 2014. Spatial and nycthemeral distribution of the zooneuston off Fernando de Noronha, Brazil. Brazilian Journal of Oceanography, 62, 35-45.

MARAFON-ALMEIDA, A., PEREIRA, J. B. \& FERNANDES, L. F. L. 2016. Distribution of the species of Lucifer Thompson, 1829 in the subtropical South Atlantic between parallels $20^{\circ}$ and $30^{\circ} \mathrm{s}$. Brazilian Journal of Oceanography, 64, 217-226.
McCONAUGHA, J. R. 1992. Decapod larvae: dispersal, mortality, and ecology. A working hypothesis. Integrative and Comparative Biology, 32, 512-523.

NEWELL, G. E. \& NEWELL, R. C. 1963. Marine plankton: a practical guide. London: Hutchlson Educational.

OMORI, M. \& IKEDA, T. 1984. Methods in marine zooplankton ecology. New York: John Willey \& Sons.

PAULA, J. 1987. Seasonal distribution of Crustacea Decapoda larvae in S. Torpes bay, South-western Portugal. Investigaciones Pesqueras, 51, 267-275.

PIELOU, E. C. 1966. The measurement of diversity in different types of biological collections. Journal of Theoretical Biology, 13, 131-144.

PIKE, R. B. \& WILLIAMSON, D. I. 1958. Crustacea Decapoda: Larvae XI. Paguridea, Coenobitidea, Dromiidea and Homolidea. ICES Fiches d'Identification du Zooplancton, 81, 1-9.

POLIS, G. A., ANDERSON, W. B. \& HOLT, R. D. 1997. Toward an integration of landscape and food web ecology: the dynamics of spatially subsidized food webs. Annual Review of Ecology and Systematics, 28, 289-316.

SAZIMA, I., SAZIMA, C. \& SILVA, J. M. 2003. The cetacean offal connection: feces and vomits of spinner dolphins as a food source for reef fishes. Bulletin of Marine Science, 72, 151-160.

SCHELTEMA, R. S. 1988. Initial evidence for the transport of teleplanic larvae of benthic invertebrates across the East Pacific Barrier. The Biological Bulletin, 174, 145-152.

SCHWAMBORN, R., EKAU, W., PINTO, A. S., SILVA, T. A., \& SAINT-PAUL, U. 1999. The contribution of estuarine decapod larvae to marine macrozooplankton communities in northeast Brazil. Archives of Fishery and Marine Research, $47,167-182$

SHANNON, C. E. 1948. A mathematical theory of communication. Bell Labs Technical Journal, 27, 379-423.

SILVEIRA, I. C. A., SCHMIDT, A. C. K., CAMPOS, E. J. D., GODOI, S. S. \& IKEDA, Y. 2000. A corrente do Brasil ao largo da costa leste brasileira. Revista Brasileira de Oceanografia, 48, 171-183.

STRAMMA, L. 1991. Geostrophic transport of the South Equatorial Current in the Atlantic. Journal of Marine Research, 49, 281-294.

STRATHMANN, R. R., HUGHES, T. P., KURIS, A. M., LINDEMAN, K. C., MORGAN, S. G., PANDOLFI, J. M. \& WARNER, R. R. 2002. Evolution of local recruitment and its consequences for marine populations. Bulletin of Marine Science, 70, 377-396.

TORRES, A. P., DOS SANTOS, A., BALBÍN, R., ALEMANY, F., MASSUTÍ, E. \& REGLERO, P. 2013. Decapod crustacean larval communities in the Balearic Sea (western Mediterranean): seasonal composition, horizontal and vertical distribution patterns. Journal of Marine Systems, 138, 112-126.

TURRA, A. \& LEITE, F. P. P. 1999. Population structure and fecundity of the hermit crab Clibanarius antillensis Stimpson 1862 (Anomura, Diogenidae) in southeastern Brazil. Bulletin of Marine Science, 64, 281-289.

WEAVER, B. L. 1990. Geochemistry of highly-undersaturated ocean island basalt suites from the South Atlantic Ocean: Fernando de Noronha and Trindade islands. Contributions to Mineralogy and Petrology, 105, 502-515. 
WILLIAMSON, D. I. 1969. Names of larvae in the Decapoda and Euphausiacea. Crustaceana, 16, 210-213.
ZAR, J. H. 1999. Biostatistical analysis, Noida, Pearson Education. 